\title{
Aging-Related Declines in Stature and its Implications on Determining Central Obesity and the Risk of Osteoporosis
}

\author{
Afrooz Afghani* \\ Milkin School of Public Health, George Washington University, USA
}

Submission: February 14, 2018; Published: February 23, 2018

*Corresponding author: Afrooz Afghani, PhD, MPH, Department of Exercise \& Nutrition Sciences, Milken Institute of Public Health, George Washington University, Washington DC, USA, Email: afghani@gwu.edu

Keywords: Abdominal obesity; Osteoporosis; Bone mass; Elderly; Stature; Waist-to-height ratio

\section{Editorial}

In our previously published work [1], the association between waist circumference as a measure of central obesity and that of low bone mass and osteoporosis risk was shown in adult women. Those findings as well as our others [2,3] in children have shown that central obesity has an inverse correlation with bone mass and can potentially increase the risk of osteoporosis. We concluded [2] that mechanistically, IGF-1 and leptin may be the mediators of the deleterious effects of abdominal fat on bone.

In the elderly, whether we should use waist circumference as a tool to investigate the correlation between central obesity and osteoporosis is an important question and worthy of future investigations. In light of the fact that waist circumference is a measure of fat accumulation around the abdomen and it does not take into account a person's height, combined with observations that there are declines in stature (i.e. height) in the elderly [4], the appropriateness of this measure in older populations should be evaluated in longitudinal studies.

Height has been utilized as a useful proxy for childhood nutritional status, growth during puberty [5], and a potential complement to other indicators of health and wellbeing [4]. However, a decline in height associated with aging is an aspect that has been somewhat overlooked. On average, physical stature declines at an annual rate of $0.08 \%$ and $0.10 \%$ for males, and $0.12 \%$ and $0.14 \%$ for females, translating to approximately a $2 \mathrm{~cm}$ to a $4 \mathrm{~cm}$ reduction over a lifetime [4]. These declines in height can be accompanied with reductions in overall body weight [4] and ultimately linked to changes in bone mass and osteoporosis risk.
Studies have shown that waist-to-height ratio (WHtR) is a better screening tool than waist circumference for cardio metabolic risk factors [6]. Because WHtR values will certainly be affected in the elderly due to their declines in stature with age, the association between WHtR and bone mass needs to be evaluated in older populations in order to determine whether it is a better measure of central adiposity and if it is inversely correlated with bone mass. In conclusion, the crisis of abdominal obesity underscores the importance of accurate and appropriate investigations in the elderly to examine its possible deleterious role on bone mass in order to minimize osteopenia and prevent osteoporosis in this vulnerable population.

\section{References}

1. Afghani A (2013) Android shape independent of aerobic fitness is a risk factor for low bone mineral content in overweight and obese Latina women. Clin Med Insights Womens Health 6: 25-30.

2. Afghani A, Goran MI (2009) The interrelationships between abdominal obesity, leptin, and bone mineral content in overweight Latino children. Horm Res 72(2): 82-87.

3. Afghani A, Goran MI (2006) Racial differences in the effects of subcutaneous and visceral fat on bone mineral content in pre-pubertal children. Calcif Tissue Int 79(6): 383-388.

4. Fernihough A, McGovern ME (2015) Physical stature decline and the health status of the elderly population in England. Econ Hum Biol 16: $30-44$

5. Deaton A (2007) Height, health, and development. Proc Natl Acad Sci USA 104(33): 13232-13237.

6. Khoury M, Manlhiot C, McCrindle BW (2013) Role of the waist/height ratio in the cardiometabolic risk assessment of children classified by body mass index. J Am Coll Cardiol 62(8): 742-751. 
This work is licensed under Creative Commons Attribution 4.0 License DOI: $10.19080 /$ NFSIJ.2018.05.555667

\section{Your next submission with Juniper Publishers} will reach you the below assets

- Quality Editorial service

- Swift Peer Review

- Reprints availability

- E-prints Service

- Manuscript Podcast for convenient understanding

- Global attainment for your research

- Manuscript accessibility in different formats ( Pdf, E-pub, Full Text, Audio)

- Unceasing customer service

Track the below URL for one-step submission https://juniperpublishers.com/online-submission.php 